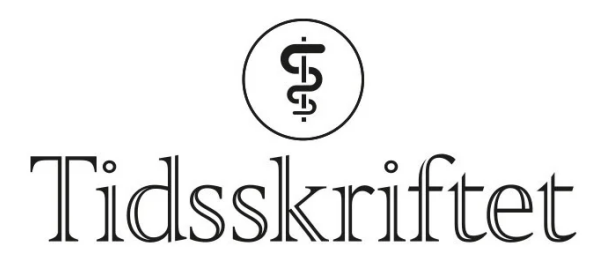

DEN NORSKE LEGEFORENING

\title{
Vi trenger deg i antidopingarbeidet
}

\author{
GJESTESKRIBENT
}

ANDERS SOLHEIM

Daglig leder i Antidoping Norge

\section{Doping med anabole steroider i ungdomsmiljøer er blitt et samfunnsproblem. Unge menn kombinerer trening med doping for å få en muskuløs kropp. Det som kan se ut som en snarvei, viser seg ofte å bli en blindgate.}

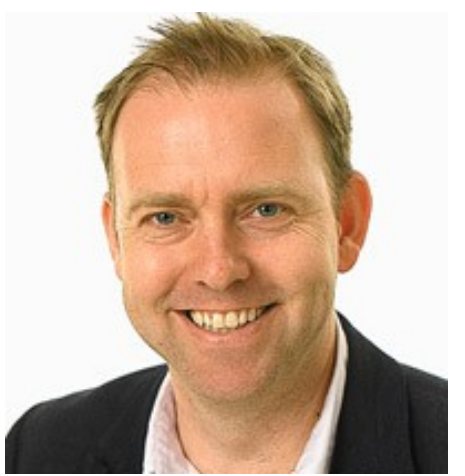

De fleste av oss er opptatt av trening fordi det er sunt. Kombinert med riktig kosthold er trening den beste forsikringen mot livsstilsykdommer. Dessverre blir enkelte mer opptatt av eget utseende enn av sunnhet og fanges av vedvarende dopingmisbruk. For mange dopingmisbrukere tar trenings- og kostholdsregimer fullstendig kontroll over tilværelsen. Kroppens utseende betyr alt. Dopingbruken oppleves som nødvendig for å nå de kroppsidealene vi blir møtt med i samfunnet.

Barland og Tangens omfangsundersøkelse om doping fra 2009 viser at de som bruker doping, i hovedsak er motivert ut fra ønsket om en penere kropp. Den ideelle mannskroppen er slank med markerte muskler. Det å ha en flott kropp oppfattes som et uttrykk for sunnhet.

Det kan virke som et paradoks at misbrukere av anabole steroider er så opptatt av egen helse. Via nettsider får misbrukeren selv god oversikt over bivirkninger. Det er ikke uvanlig at de oppsøker lege for en helsesjekk. Distributører av illegale anabole steroider oppfordrer faktisk brukerne til å sjekke sine leververdier. Misbrukeren kan komme med ønske om resept på antiøstrogene midler for å motvirke forstørrede bryster. Andre ønsker hjelp for 
kviser eller barnløshet. Seneruptur kan forekomme, og varsellampene bør blinke hvis du samtidig ser strekkmerker over muskulatur. Humørsvingninger og aggressiv atferd kan føre til skader og legebesøk både for misbrukeren og personer i hans nærhet.

Langvarig misbruk kan ødelegge unge menneskeliv. Pårørende kjenner ikke igjen barna sine. Kostnadene for den enkelte familie og samfunnet kan bli betydelige.

Ut fra de senere årenes omfangsundersøkelser kan vi anslå at cirka tre prosent av gutter bruker eller har brukt dopingmidler, og trolig foreligger underrapportering. Dette innebærer snaut 1 ooo unge for hvert årskull. Misbruket forekommer helt fra tidlig i ungdomsskolen og inn i godt voksen alder. Det er derfor sannsynlig at det vedrører noen av dine pasienter. Ved å stille de rette spørsmålene kan du få tak i årsakene fremfor å behandle symptomene.

En betydelig andel av de illegale dopingmidlene som brukes, er fremstilt i Norge med ulovlig importert råmateriale. Produkter som for misbrukeren tilsynelatende ser ut som ekte og fabrikkprodusert vare, er med stor sannsynlighet produsert under uhygieniske forhold i en lokal garasje eller kjeller. NRK Brennpunkt viste i fjor høst at fire av 15 illegale preparater hadde store feil i forhold til hva etiketten lovet. Når misbrukerne ikke vet hva de inntar, er mulighetene for bivirkninger og interaksjoner betydelige.

For fremtiden er det avgjørende at bivirkninger og skader som følge av dopingbruk, registreres. Per i dag er det vår oppfatning at det ikke er nok kunnskap og dokumentasjon på dette feltet. Vi har rettet en forespørsel til Regionalt legemiddelinformasjonssenter (RELIS) og Statens legemiddelverk om samarbeid når det gjelder rapportering av bivirkninger knyttet til bruk av dopingmidler. På den måten kan vi få større innsikt i hvilke helsekonsekvenser misbruket medfører. En systematisert oversikt over hvilke diagnoser som er fremtredende for brukere av anabole steroider og andre dopingmidler, er etterspurt. Antidoping Norge inviterer personer som jobber med unge i risikosonen til lokale seminarer en rekke steder i landet. Det er mange som uttrykker bekymring. Kunnskapen om psykiske, fysiske og sosiale bivirkninger er begrenset, og det haster med å intensivere det forebyggende arbeidet. Antidoping Norge ønsker å bygge opp regionale kunnskapsnettverk som kan ta aktivt del i antidopingarbeidet og dele erfaringer og utfordringer. Ønsker du å være med, vil det utvilsomt styrke antidopingarbeidet. Ved å investere litt av din tid tror vi at du kan få utrettet mye.

Vær oppmerksom på problemer knyttet til misbruk av anabole stoffer!

Publisert: 18. februar 2011. Tidsskr Nor Legeforen. DOI:10.4045/tidsskr.11.0023

(C) Tidsskrift for Den norske legeforening 2023. Lastet ned fra tidsskriftet.no 26. april 2023. 